\title{
PEMBELAJARAN TEMATIK INTEGRATIF IPA DAN IPS DI MADRASAH IBTIDAIYAH PADA KURIKULUM 2013
}

\author{
Oleh
}

Novianti Muspiroh, M.P.

\begin{abstract}
Natural science and social science are integrated into the 2013 curriculum based on the themes in all subjects of Madrasah Ibtidaiyah (MI) (Islamic Primary School). The integration is done in two ways, namely the integration of attitudes, skills and knowledge in the learning process and the related basic concepts. Themes related to the meaning of the basic concepts, so students do not learn them partially. This approach is appropriate for MI students because of the psychological point of view; they have not been able to think abstractly to understand content of a separate subject. Thereby, the classroom atmosphere are comfortable and fun, students can learn to solve social problems and mutual respect, they get opportunities as possible to learn better, get the information quickly, apply materials directly in the context of daily life, and apply the principle of mastery learning.
\end{abstract}

Keywords: Tematik, IPA, IPS, Madrasah Ibtidaiyah

\section{A. Pendahuluan}

Belum genap 10 tahun Kurikulum Berbasis Kompetensi (KBK/2004) dan Kurikulum Tingkat Satuan Pendidikan (KTSP/2006) diterapkan, pemerintah melalui Kementrian Pendidikan dan Kebudayaan (Kemendikbud) membuat kurikulum baru yang diberi nama Kurikulum 2013. Sejak 29 November 2012 lalu Kemendikbud telah mengumumkan draft resmi Kurikulum 2013.

Dalam perubahan kurikulum tersebut, khusus untuk jenjang Madrasah Ibtidaiyah (MI) mengalami banyak perubahan standar isi kurikulum. Di MI akan diterapkan sistem pembelajaran berbasis tematik integratif. Kurikulum 2013 itu mengurangi jumlah mata pelajaran MI menjadi 6 yang saat ini ada 10 mata pelajaran, yaitu: Pendidikan Agama, Pendidikan Kewarganegaraan, Bahasa Indonesia, Matematika, IPA, IPS, Seni Budaya dan Keterampilan, Pendidikan Jasmani Olahraga dan Kesehatan, serta Muatan lokal dan Pengembangan diri.

Enam mata pelajaran yang diajarkan di MI pada kurikulum 2013 itu adalah Matematika, Bahasa Indonesia, Agama, Pendidikan Jasmani, 
Pendidikan Pancasila dan Kewarganegaraan, dan Seni Budaya. Ilmu Pengetahuan Alam (IPA) dan Ilmu Pengetahuan Sosial (IPS) yang sebelumnya diajarkan di MI, akan diajarkan secara terpadu atau terintegrasi dengan mata pelajaran yang lain. Berita sebelumnya menyebutkan untuk mata pelajaran IPA akan menjadi materi pembahasan pelajaran Bahasa Indonesia dan Matematika.

Dengan diterapkannya sistem pembelajaran berbasis tematik integratif di kurikulum 2013, mata pelajaran IPA dan IPS bukannya dihapus dari kurikulum, tapi diintegrasikan berdasarkan tema. Mata pelajaran IPA dan IPS akan menjadi materi bahasan di semua mata pelajaran. Intinya, yang dihapuskan adalah nama pelajarannya, IPA dan IPS. Tapi substansi pelajaran IPA dan IPS tidak ada satu pun yang dihilangkan. Prosesnya, tema-tema yang ada di dua mata pelajaran itu diintegrasikan kepada enam mata pelajaran yang akan menjadi muatan pelajaran MI.

Tiga alternatif yang menentukan nasib mata pelajaran IPA dan IPS pada uji publik kurikulum 2013 itu adalah: (1.) Nama mata pelajaran IPA dan IPS sama sekali tidak dimunculkan, hanya muatannya yang muncul di pelajaranpelajaran lain. (2.), IPA dan IPS akan dimunculkan sebagai nama mata pelajaran mulai kelas 4 MI sampai 6 MI. (3.), IPA dan IPS hanya akan dimunculkan sebagai pelajaran tersendiri untuk kelas 5 dan 6 MI.

\section{B. Pengertian Pendekatan Tematik Integratif IPA dan IPS Kurikulum 2013}

Pendekatan tematik terpadu (integrated thematic instruction) merupakan pendekatan pembelajaran yang memadukan pokok bahasan pada beberapa mata pelajaran (Aminudin, 1994) minimal dua mata pelajaran atau lebih yang dalam hal ini IPA dan IPS menjadi satu tema yang berkaitan studi untuk memberikan pengalaman bermakna kepada siswa.

Pada dasarnya pembelajaran tematik terpadu IPA dan IPS merupakan suatu sistem pembelajaran yang memungkinkan siswa baik individu maupun kelompok aktif mencari, menggali, dan menemukan konsep serta prinsip keilmuan secara holistik, bermakna, dan otentik yang ada pada pelajaran tersebut. Melalui pembelajaran terpadu siswa dapat pengalaman langsung 
dalam proses belajarnya, hal ini dapat menambah daya kemampuan siswa semakin kuat tentang hal-hal yang dipelajarinya.

Kurikulum 2013 menyarankan keutamaan penggunaan pendekatan ini. Struktur Kurikulum 2013 merupakan acuan dalam merancang pembelajaran yang akan menjadi landasan penetapan prosentase penyajian pembelajaran. Di kelas I sampai dengan kelas VI Madrasah Ibtidaiyah (MI) membelajarkan materi dengan tema sebagai pemersatunya, tidak parsial per mata pelajaran IPA dan IPS.

Premis utama Pendekatan Tematik Terpadu adalah bahwa siswa membutuhkan kesempatan-kesempatan tambahan (additional opportunities) agar dapat memanfaatkan bakat dan talentanya, menyediakan waktu bersama yang lain untuk secara cepat mengkonseptualisasi dan mensintesis. Di lain pihak, pendekatan ini cocok untuk mengakomodasi perbedaan-perbedaan kualitatif terkait lingkungan belajar yang ada di sekitar siswa. Pendekatan tematik terpadu jika diimplementasikan pada siswa Madrasah Ibtidaiyah maka diharapkan akan dapat memberikan inspirasi kepada siswa dalam memperoleh pengalaman belajar.

\section{Prinsip-prinsip Pembelajaran Tematik Integratif IPA dan IPS}

Ada beberapa prinsip-prinsip dalam pembelajaran tematik terpadu IPA dan IPS yang harus diperhatikan oleh guru yaitu meliputi:

1. Prinsip penggalian tema antara lain:

a. Tema hendaknya tidak terlalu luas, namun dengan mudah dapat digunakan memadukan banyak bidang studi.

b. Tema harus bermakna artinya bahwa tema yang dipilih untuk dikaji harus memberikan bekal bagi siswa untuk belajar selanjutnya.

c. Tema harus disesuaikan dengan tingkat perkembangan psikologis anak.

d. Tema yang dikembangkan harus mampu mewadahi sebagian besar minat anak.

e. Tema yang dipilih hendaknya mempertimbangkan penstiwa-peristiwa otentik yang terjadi dalam rentang waktu belajar. 
f. Tema yang dipilih hendaknya mempertimbangkan kurikulum yang berlaku, serta harapan dari masyarakat.

g. Tema yang dipilih hendaknya juga mempertimbangkan ketersediaan sumber belajar.

2. Prinsip pelaksanaan terpadu di antaranya:

a. Guru hendaknya tidak bersikap otoriter dan jangan menjadi "single

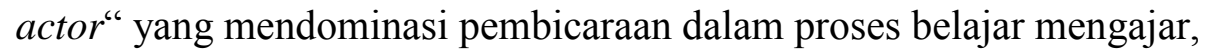

b. Pemberian tanggungjawab individu dan kelompok harus jelas dalam setiap tugas yang menuntut adanya kerjasama kelompok,

c. Guru perlu akomodatif terhadap ide-ide yang terkadang sama sekali tidak terpikirkan dalam poses perencanaan.

3. Prinsip evaluatif adalah:

a. Memberi kesempatan kepada siswa untuk melakukan evaluasi diri di samping bentuk evaluasi lainnya,

b. Guru perlu mengajak siswa untuk mengevaluasi perolehan belajar yang telah dicapai berdasarkan kriteria keberhasilan pencapaian tujuan yang telah disepakati dalam kontrak.

4. Prinsip reaksi

Dampak pengiring yang penting bagi perilaku secara sadar belum tersentuh oleh guru dalam kegiatan belajar mengajar. Karena itu, guru dituntut agar mampu merencanakan dan melaksanakan pembelajaran sehingga tercapai secara tuntas tujuan-tujuan pembelajaran. Guru harus bereaksi terhadap reaksi siswa dalam semua "event" yang tidak diarahkan ke aspek yang sempit tetapi ke suatu kesatuan utuh dan bermakna.

\section{Pembelajaran Tematik Integratif IPA dan IPS di Madrasah Ibtidaiyah}

Kurikulum Madrasah Ibtidaiyah Tahun 2013 menggunakan pendekatan pembelajaran tematik integratif dari kelas I sampai kelas VI. Pembelajaran tematik integratif merupakan pendekatan pembelajaran yang mengintegrasikan berbagai kompetensi dari berbagai mata pelajaran ke dalam berbagai tema. Tema adalah pokok pikiran atau gagasan pokok yang menjadi pokok pembicaraan (Poerwadarminta, 1983). 
Pengintegrasian tersebut dilakukan dalam dua hal, yaitu integrasi sikap, keterampilan dan pengetahuan dalam proses pembelajaran dan integrasi berbagai konsep dasar yang berkaitan. Tema merajut makna berbagai konsep dasar sehingga peserta didik tidak belajar konsep dasar secara parsial. Dengan demikian pembelajaran IPA dan IPS memberikan makna yang utuh kepada peserta didik seperti tercermin pada berbagai tema yang tersedia.

Dalam pembelajaran tematik integratif IPA dan IPS, tema yang dipilih berkenaan dengan alam dan kehidupan sosial manusia. Untuk kelas I, II, dan III MI, keduanya merupakan pemberi makna yang substansial terhadap mata pelajaran PPKn, Bahasa Indonesia, Matematika, Seni-Budaya dan Prakarya, serta Pendidikan Jasmani, Olah Raga dan Kesehatan. Di sinilah Kompetensi Dasar dari IPA dan IPS yang diorganisasikan ke mata pelajaran lain memiliki peran penting sebagai pengikat dan pengembang Kompetensi Dasar mata pelajaran lainnya.

Kebijakan pembelajaran tematik terpadu di Madrasah Ibtidaiyah disokong dengan penyediaan buku siswa dan buku guru untuk pembelajaran masing-masing tema. Ini tentu saja berbeda dengan kebijakan kurikulum sebelumnya, yang tidak secara eksplisit disebut dalam dokumen yuridisnya (semacam peraturan menteri), maka dalam Kurikulum 2013 untuk MI semua jenjang kelas harus menggunakan pembelajaran tematik terpadu untuk semua mata pelajaran, kecuali Pendidikan Agama dan Budi Pekerti.

Dalam setiap buku tematik terpadu di Kelas 1 dan 4 MI menjelaskan bahwa pembelajaran tematik terpadu seperti dimuat dalam buku-buku tersebut merujuk dan untuk itu berbasis kompetensi dari mata-mata pelajaran yang ditematikkan. Dengan demikian pembelajaran tematik terpadu sebagai unsur Kurikulum 2013 di MI juga mengacu pada kurikulum berbasis kompetensi. Pembelajarannya pun dirancang untuk dicapai melalui proses pembelajaran berbasis penemuan (discovery learning) melalui kegiatan-kegiatan berbentuk tugas (project based learning) yang mencakup proses-proses: mengamati, menanya, mencoba, menalar, dan mengkomunikasikan. Buku siswa 
pembelajaran tematik terpadu memuat materi yang terdapat dalam matamata pelajaran di MI dan pembelajarannya berbasis aktivitas. Siswa mempelajari semua mata pelajaran secara terpadu melalui tema-tema kehidupan yang dijumpai peserta didik sehari-hari. Proses pembelajarannya pun bersifat transdisipliner dimana kompetensi yang diajarkan dikaitkan dengan konteks peserta didik dan lingkungannya. Materi mata-mata pelajaran dikaitkan satu sama lain sebagai satu kesatuan membentuk pembelajaran multidisipliner dan inter- disipliner untuk menghindari tumpang tindih dan ketidak selarasan antar materi mata pelajaran.

Dalam buku guru untuk MI kelas 1 dan 4, tampak bahwa pembelajaran tematik terpadu menggunakan pola atau model berjaring laba-laba. Model ini berangkat dari pendekatan tematis sebagai acuan dasar bahan dan kegiatan pembelajaran. Tema yang dibuat dapat mengikat kegiatan pembelajaran, baik dalam mata pelajaran tertentu maupun antarmata pelajaran (Kementerian Pendidikan dan Kebudayaan, 2013).

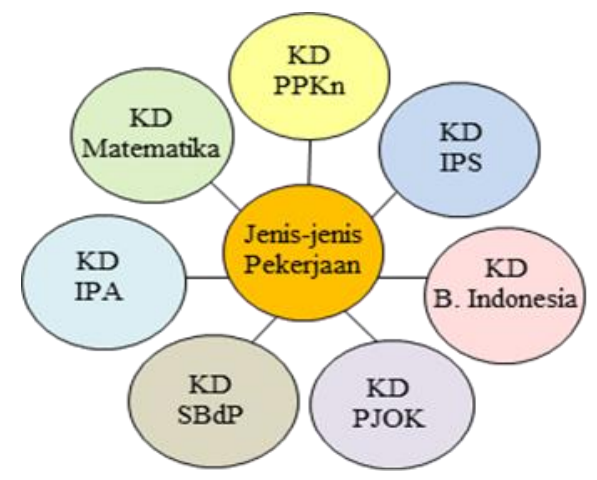

Gambar 1. Model Laba-laba Pembelajaran Tematik Terpadu Tema Jenis-Jenis

\section{Pekerjaan}

Dengan memperhatikan gambar di atas, maka tampak jelas bahwa tema berperan sebagai pemersatu kegiatan pembelajaran yang memadukan beberapa mata pelajaran sekaligus dengan membuat/mengangkat sebuah tema yang dapat mempersatukan indikator dari mata-mata pelajaran: PPKn; Bahasa Indonesia; Matematika; IPA; IPS; Seni-Budaya dan Prakarya; serta, Pendidikan Jasmani, Olah Raga dan Kesehatan.

Tabel 1. Tema-tema Pembelajaran MI Kelas I - III 


\begin{tabular}{|l|l|l|}
\hline \multicolumn{1}{|c|}{ Kelas I } & \multicolumn{1}{|c|}{ Kelas II } & \multicolumn{1}{c|}{ Kelas III } \\
\hline 1. Diriku & 1. Hidup Rukun & 1. Sayangi Hewan dan Tumbuhan di \\
2. Kegemaranku & 2. Bermain di & Sekitar \\
3. Kegiatanku & Lingkunganku & 2. Pengalaman yang Mengesankan \\
4. Keluargaku & 3. Tugas Sehari-hari & 3. Mengenal Cuaca dan Musim \\
5. Pengalamanku & 4. Aku dan Sekolahku & 4. Ringan Sama Dijinjing Berat Sama \\
6. Lingkungan Asri & 5. Hidup Bersih dan & Dipikul \\
7. Benda, Binatang, dan & Sehat & 5. Berolah raga \\
Tanaman di sekitarku & 6. Matahari & 6. Indahnya Persahabatan \\
8. Peristiwa Alam & 7. Merawat Hewan dan & 7. Mari Kita Hemat Energi untuk Masa \\
& Tumbuhan & Depan \\
& 8. Keselamatan di rumah \\
& dan di perjalanan & 8. Berperilaku Baik dalam Kehidupan \\
& & 9. Mehari-hari \\
& &
\end{tabular}

Tabel 2. Tema-tema Pembelajaran MI Kelas IV - VI

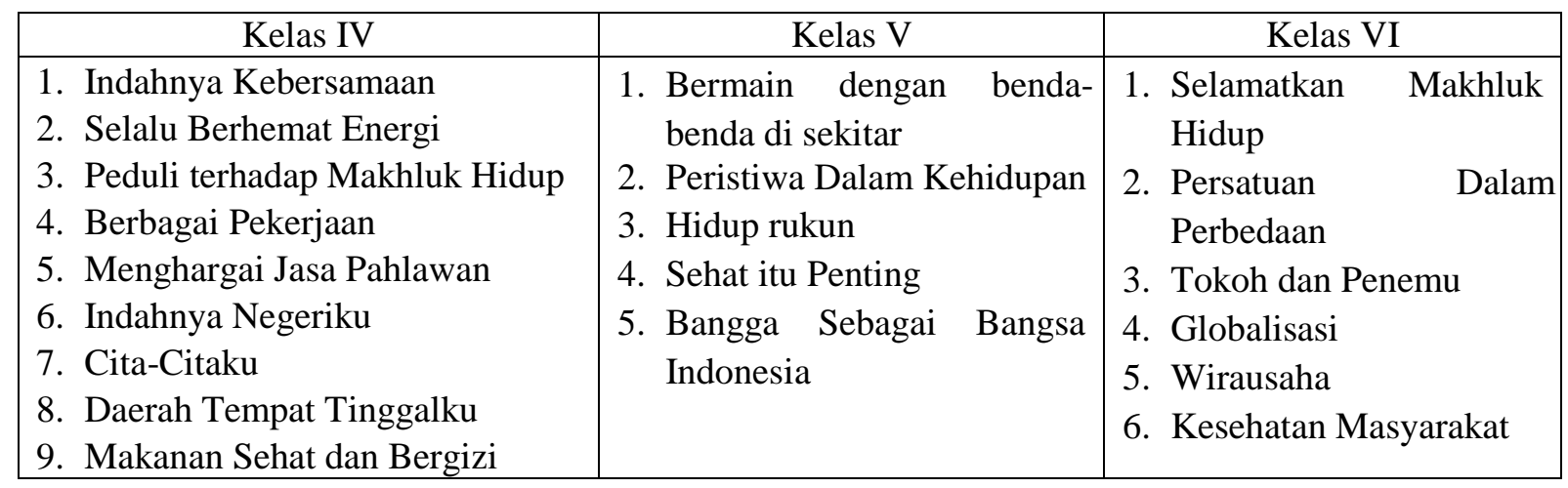

Pembelajaran tematik integratif IPA dan IPS lebih menekankan pada penerapan konsep belajar sambil melakukan sesuatu (learning by doing). Oleh karena itu, guru perlu mengemas atau merancang pengalaman belajar yang akan mempengaruhi kebermaknaan belajar siswa (meaningful learning). Pengalaman belajar yang menunjukkan kaitan unsur-unsur konseptual menjadikan proses pembelajaran lebih efektif. Kaitan konseptual antar mata pelajaran yang dipelajari akan membentuk skema, sehingga siswa akan memperoleh keutuhan dan kebulatan pengetahuan. Selain itu, dengan penerapan pembelajaran tematik di MI akan sangat membantu siswa, karena sesuai dengan tahap perkembangannya siswa yang masih melihat segala sesuatu sebagai satu keutuhan (holistic).

Belajar bermakna merupakan suatu proses pengkaitan informasi baru pada konsep-konsep relevan yang terdapat dalam struktur kognitif seseorang. 
Proses belajar tidak sekedar menghafal konsep-konsep atau fakta-fakta belaka, tetapi merupakan kegiatan menghubungkan konsep-konsep untuk menghasilkan pemahaman yang utuh, sehingga konsep yang dipelajari akan dipahami secara baik dan tidak mudah dilupakan. Belajar akan lebih bermakna apabila anak mengalami langsung apa yang dipelajarinya dengan mengaktifkan lebih banyak indera secara utuh, dari pada hanya mendengarkan penjelasan guru saja dan secara terpisah-pisah. Oleh karena itu, pembelajaran yang menyajikan mata pelajaran secara terpisah pada kelas awal, akan menyebabkan kurang berkembangnya berpikir holistik dan membuat kesulitan dalam memahami konsep, sehingga berdampak pada tingginya angka mengulang kelas dan angka putus sekolah pada kelas awal tersebut.

Di MI, semua mata pelajaran dilaksanakan dengan tematik integratif berdasarkan tema-tema yang sudah disusun. Indikator IPA dan IPS mulai muncul di kelas IV hingga VI, tetapi pembelajarannya tetap tematik integratif. Mata pelajaran IPA dan IPS di MI tidak diajarkan secara terpisah, tetapi indikatornya dibuat muncul atau diperjelas sejak kelas IV MI. Hal ini sejalan dengan masukan yang dijaring pemerintah selama uji publik terhadap perubahan Kurikulum 2013 pada akhir 2012. Misalnya, ketika membahas sungai di Bahasa Indonesia, dari sisi IPA masuk materi soal curah hujan, lingkungan, dan sebagainya. Materi IPS-nya masuk dalam bentuk manfaat sungai bagi masyarakat, perlunya menjaga lingkungan, dan sebagainya.

Berdasarkan pola tematik integratif ini, buku-buku siswa MI tidak lagi dibuat berdasarkan mata pelajaran, tetapi berdasarkan tema yang merupakan gabungan dari beberapa mata pelajaran yang relevan dengan kompetensi di MI. Sebagai contoh, untuk kelas I MI ada delapan tematik, yakni diriku; kegemaranku; kegiatanku; keluargaku; pengalamanku; lingkungan bersih, sehat, dan asri; benda, binatang, dan tanaman di sekitarku; serta peristiwa alam. Ada juga pendidikan agama dan budi pekerti.

\section{E. Landasan Pembelajaran Tematik}

Secara filosofis, kemunculan pembelajaran tematik sangat dilandasi oleh tiga aliran filsafat berikut: (1) progresivisme, (2) konstruktivisme, dan (3) 
humanisme.

1. Aliran progresivisme beranggapan bahwa proses pembelajaran pada umumnya perlu sekali ditekankan pada: (a) pembentukan kreatifitas, (b) pemberian sejumlah kegiatan, (c) suasana yang alamiah (natural), dan (d) memperhatikan pengalaman siswa. Dengan kata lain proses pembelajaran itu bersifat mekanistis (Ellis, 1993). Aliran ini juga memandang bahwa dalam proses belajar, siswa sering dihadapkan pada persoalan-persoalan yang harus mendapatkan pemecahan atau bersifat "problem solving". Dalam memecahkan masalah tersebut, siswa perlu memilih dan menyusun ulang pengetahuan dan pengalaman belajar yang telah dimilikinya. Dalam hal demikian maka terjadi proses berpikir yang terkait dengan "metakognisi", yaitu proses menghubungkan pengetahuan dan pengalaman belajar dengan pengetahuan lain untuk menghasilkan sesuatu (J. Marzano et al, 1992). Terdapatnya kesalahan atau kekeliruan dalam proses pemecahan masalah atau sesuatu yang dihasilkan adalah sesuatu yang wajar, karena hal itu merupakan bagian dari proses belajar.

2. Aliran konstruktivisme melihat pengalaman langsung siswa (direct experiences) sebagai kunci dalam pembelajaran. Sebab itu, pengalaman orang lain yang diformulasikan misalnya dalam suatu buku teks perlu dihubungkan dengan pengalaman siswa secara langsung. Aliran konstruktivisme ini menekankan bahwa pengetahuan adalah hasil konstruksi atau bentukan manusia. Manusia mengkonstruksi pengetahuannya melalui interaksi dengan obyek, fenomena, pengalaman dan lingkungannya. Suatu pengetahuan dianggap benar bila pengetahuan itu dapat berguna untuk menghadapi dan memecahkan persoalan atau fenomena yang sesuai.

3. Aliran humanisme melihat siswa dari segi: (a) keunikan/kekhasannya, (b) potensinya, dan (c) motivasi yang dimilikinya. Siswa selain memiliki kesamaan juga memiliki kekhasan. Implikasi dari hal tersebut dalam kegiatan pembelajaran yaitu: (a) layanan pembelajaran selain bersifat klasikal, juga bersifat individual, (b) pengakuan adanya siswa yang lambat (slow learner) dan siswa yang cepat, (c) 
penyikapan yang unik terhadap siswa baik yang menyangkut faktor personal/individual maupun yang menyangkut faktor lingkungan sosial/kemasyarakatan.

Selain landasan filosofis di atas, pembelajaran tematik juga dilandasi oleh beberapa pandangan psikologis. Dari sudut pandang psikologis, peserta didik belum mampu berpikir abstrak untuk memahami konten mata pelajaran yang terpisah kecuali kelas IV, V, dan VI MI sudah mulai mampu berpikir abstrak. Pandangan psikologi perkembangan dan Gestalt memberi dasar yang kuat untuk integrasi Kompetensi Dasar yang diorganisasikan dalam pembelajaran tematik. Dari sudut pandang transdisciplinarity maka pengotakan konten kurikulum secara terpisah ketat tidak memberikan keuntungan bagi kemampuan berpikir selanjutnya.

Peserta didik MI berada pada rentang usia dini. Masa usia dini merupakan masa yang pendek, tetapi sangat penting bagi kehidupan seseorang, karena pada masa ini seluruh potensi yang dimiliki anak perlu didorong sehingga akan berkembang secara optimal. Pada usia dini tersebut, berbagai kecerdasannya seperti IQ, EQ, dan SQ tumbuh dan berkembang sangat pesat, dan tingkat perkembangannya masih melihat segala sesuatu sebagai satu keutuhan (holistic), serta memahami hubungan antar konsep secara sederhana. Proses pembelajaran masih bergantung kepada objek kongkret dan pengalaman langsung.

Belajar adalah proses perubahan di dalam kepribadian berupa kecakapan, sikap, kebiasaan, dan kepandaian. Perubahan ini bersifat menetap dalam tingkah laku yang terjadi sebagai hasil dari latihan atau pengalaman. Pembelajaran adalah suatu proses interaksi antar anak dengan anak, anak dengan sumber belajar, dan anak dengan guru/pendidik (Daniel L. Schacter, et al., 2011:264).

Pembelajaran tematik integratif lebih menekankan pada keterlibatan siswa dalam proses belajar secara aktif dalam proses pembelajaran, sehingga siswa dapat memperoleh pengalaman langsung dan terlatih untuk dapat menemukan sendiri berbagai pengetahuan yang dipelajarinya. Melalui 
pengalaman langsung siswa akan memahami konsep-konsep yang mereka pelajari dan menghubungkannya dengan konsep lain yang telah dipahaminya.

Selain dimotori oleh teori pembelajaran Gestalt, pembelajaran ini dimotori pula oleh Piaget yang menekankan bahwa pembelajaran haruslah bermakna dan berorientasi pada kebutuhan dan perkembangan anak. Piaget (1950) menyatakan bahwa setiap anak memiliki cara tersendiri dalam menginterpretasikan dan beradaptasi dengan lingkungannya (teori perkembangan kognitif). Menurutnya, setiap anak memiliki struktur kognitif yang disebut schemata yaitu sistem konsep yang ada dalam pikiran sebagai hasil pemahaman terhadap objek yang ada dalam lingkungannya. Pemahaman terhadap objek tersebut berlangsung melalui proses asimilasi (menghubungkan objek dengan konsep yang sudah ada dalam pikiran) dan akomodasi (proses memanfaatkan konsep-konsep dalam pikiran untuk menafsirkan objek). Jika kedua proses tersebut berlangsung terus-menerus, akan membuat pengetahuan lama dan pengetahuan baru menjadi seimbang, sehingga secara bertahap anak dapat membangun pengetahuan melalui interaksi diri anak dengan lingkungannya.

Anak usia Madrasah Ibtidaiyah berada pada tahapan operasional kongkret dan perilaku belajarnya, (1) mulai memandang dunia secara objektif, bergeser dari satu aspek ke aspek lain secara reflektif dan serentak, (2) mulai berpikir secara operasional, (3) berpikir operasional untuk mengklasifikasikan benda-benda, (4) membentuk dan mempergunakan keterhubungan aturanaturan, prinsip ilmiah sederhana dan mempergunakan hubungan sebab akibat, (5) memahami konsep substansi, volume, panjang, lebar, luas, dan berat. Ciri belajar anak usia Madrasah Ibtidaiyah adalah, (1) kongkret (dapat dilihat, didengar, dibau, dikecap, diraba, dan diotak-atik), (2) integratif (segala sesuatu dipandang sebagai satu keutuhan), (3) hierarkis (urut, logis, keterkaitan antar materi, cakupan keluasan dan kedalaman materi).

\section{F. Memperkaya Materi}

Indikator sains (IPA) yang menonjol dalam pembelajaran tematik integratif dengan IPS mulai di kelas IV Madrasah Ibtidaiyah memberikan 
ruang bagi guru untuk memperkaya materi sains. Apalagi ada sekolah-sekolah yang memang ingin meningkatkan pendidikan sains mulai jenjang pendidikan dasar (MI). Atas dasar pemikiran tersebut, maka pembelajaran yang sesuai dengan tingkat perkembangan anak MI adalah pembelajaran yang dikelola secara terpadu melalui pendekatan tematik.

Perubahan Kurikulum 2013 tersebut merupakan kurikulum minimal. Guru dan sekolah tetap punya keleluasaan untuk mengembangkan atau memperkaya materi. Yang penting, kompetensi minimalnya sudah terpenuhi. Dengan kata lain, Kurikulum 2013 menuntut guru untuk lebih bisa mengembangkan cara pembelajaran yang asyik dan menyenangkan. Proses ini mungkin tidak akan serta merta berubah dalam diri guru yang selama ini biasa "mencekoki" siswa dengan penjelasan-penjelasan gaya satu arah. Oleh karena itu, guru harus bisa memposisikan diri sebagai pembimbing siswa bukan sang otoriter kelas. Masalah bakat dan minat, hanya siswa sendiri yang bisa mengenali dirinya sendiri. Inilah konsep Kurikulum 2013 yang lebih "memanusiakan manusia". Bukan menjadikan siswa "robot pendidikan" yang cepat lelah dan pusing karena harus mengerjakan tugas sekolah yang begitu banyak, belum lagi aneka buku yang harus dia bawa di tas karena banyaknya pelajaran yang harus dia pelajari.

Guru diharapkan mampu menggali dan memancing potensi siswa, apapun minat dan bakatnya. Siswa sendiri menjadi obyek yang diberi keleluasaan untuk mengembangkan potensi dirinya. Dengan demikian, tidak ada lagi dikotomi (tepatnya kasta) mata pelajaran yang menyebabkan munculnya label seorang anak disebut "pintar" atau "kurang pintar" dengan berpatokan pada mata pelajaran tertentu yang dianggap memiliki nilai tersendiri. Mau pelajaran sains, sosial, atau bahasa semua sama "haknya" yang bebas dipilih oleh siswa. Tentunya hal ini menimbulkan ekses lain, salah satunya dengan persiapan sumber daya manusia (baca: guru) dan infrastruktur yang mendukung bagi perkembangan siswa dan sekolah.

Pengalaman belajar dalam Kurikulum sebelumnya, yang cenderung disipliner, sarat beban materi kognitif, over lapping antar materi yang sama di 
mata pelajaran berbeda, antara lain salah satu sebab perlunya pembelajaran tematik terpadu penting diterapkan sejak di pendidikan dasar (MI). Oleh Pengembang Kurikulum 2013 diyakini bahwa pembelajaran tematik terpadu merupakan sebagai salah satu model pengajaran yang efektif (highly effective teaching model). Selain itu, pembelajaran tematik terpadu dianggap mampu mewadahi dan menyentuh secara terpadu dimensi emosi, fisik, dan akademik (Kementerian Pendidikan dan Kebudayaan, 2013).

Pengembangan materi ajar pada pendekatan integratif kurikulum 2013 berdasarkan prinsip bahwa peserta didik memiliki posisi sentral untuk mengembangkan kompetensinya agar menjadi manusia yang beriman dan bertakwa kepada Tuhan Yang Maha Esa, berakhlak mulia, sehat, berilmu, cakap, kreatif, mandiri dan menjadi warga negara yang demokratis serta bertanggung jawab. Untuk mendukung pencapaian tujuan tersebut pengembangan kompetensi peserta didik disesuaikan dengan potensi, perkembangan, kebutuhan, dan kepentingan peserta didik serta tuntutan lingkungan. Memiliki posisi sentral berarti kegiatan pembelajaran berpusat pada peserta didik.

Pengembangan materi juga harus tanggap terhadap perkembangan ilmu pengetahuan, teknologi dan seni Kurikulum dikembangkan atas dasar kesadaran bahwa ilmu pengetahuan, teknologi dan seni yang berkembang secara dinamis. Oleh karena itu, semangat dan materi memberikan pengalaman belajar peserta didik untuk mengikuti dan memanfaatkan perkembangan ilmu pengetahuan, teknologi, dan seni.

\section{G. Manfaat Pembelajaran Tematik Integratif IPA dan IPS di Madrasah \\ Ibtidaiyah}

Banyak manfaat yang dapat diraih oleh pembelajaran yang mengimplementasikan pendekatan pembelajaran ini. Berikut beberapa di antaranya:

1. Melalui penerapan pendekatan pembelajaran tematik terpadu IPA dan IPS maka akan tercipta suasana kelas yang nyaman dan menyenangkan. 
Suasana kelas memungkinkan semua orang yang ada di dalamnya (utamanya siswa dan guru) akan mempunyai perasaan bersedia menanggung resiko bersama-sama. Contohnya saja, semua orang yang ada di dalam kelas akan berusaha menanggapi pertanyaan-pertanyaan yang bahkan berupa pertanyaan yang tidak semestinya atau tidak benar tanpa harus menyinggung perasaan sang penanya. Prosedur-prosedur kerja keseharian, memastikan bahwa semua jadwal dapat diprediksi, dan terdapat jaminan bahwa siswa akan merasa aman saat berada di kelas maupun di luar kelas. Keterampilan hidup yang dipelajari dapat dikenali, didiskusikan dan dipraktikkan oleh siswa dengan interaksi yang tepat dan dengan perasaan senang di dalam komunitasnya di ruang kelas.

2. Penerapan pendekatan pembelajaran tematik terpadu IPA dan IPS mendorong siswa untuk belajar memecahkan masalah sosial dan saling menghargai

Di dalam kehidupan mereka nanti pada saat bermasyarakat di usia dewasanya, siswa-siswa kelas rendah sangat perlu untuk menguasai berbagai keterampilan sosial. Mereka harus mampu dan mempunyai keterampilan bekerjasama di dalam kelompoknya, melakukan kolaborasi dengan berbagai rekan kerja atau siapa saja, belajar berada di dalam kelompok, dan kemampuan memecahkan konflik di antara anggota kelompok yang selanjutnya akan mendodong mereka untuk dapat memecahkan masalah sosial di sekitarnya dengan tetap saling menghargai.

3. Lingkungan belajar yang ramah pada pendekatan pembelajaran terpadu tematik IPA dan IPS memberikan peluang sebesar-besarnya bagi siswa untuk belajar dengan lebih baik

Di dalam pembelajaran yang menggunakan model pembelajaran tematik terpadu IPA dan IPS, guru harus dapat menggunakan seoptimal mungkin semua lingkungan belajar yang ada di sekitar. Optimalisasi lingkungan belajar akan menciptakan kelas menjadi tempat yang ramah otak untuk pembelajaran. Dengan cara ini, maka guru telah memberikan peluang yang sebesar-besarnya bagi semua siswa untuk mengeksplorasi materi ajar 
secara luas dan mendalam, kemudian melibatkan mereka secara langsung dalam aktivitas belajar-mengajar.

4. Kecepatan proses pengolahan informasi oleh siswa melalui pendekatan pembelajaran tematik terpadu IPA dan IPS

Siswa, melalui pendekatan pembelajaran tematik terpadu IPA dan IPS akan membuat para siswa secara cepat dan tepat waktu mampu memproses informasi yang disediakan. Proses pengolahan informasi oleh siswa ini tentu tidak hanya dalam hal kuantitas, tetapi yang penting juga adalah kualitasnya. Melalui pendekatan tematik terpadu dapat membantu siswa dalam mengeksplorasi konsep-konsep baru dan membantu mereka agar siap mengembangkan pengetahuannya.

5. Aplikasi materi pembelajaran langsung dalam konteks kehidupan sehari-hari (real life situation)

Beberapa waktu yang lalu santer dibicarakan tentang pembelajaran di kelas yang harus berangkat dari masalah nyata dari kehidupan sehari-hari siswa (real life situation) atau kontekstual. Pembelajaran tematik terpadu adalah pembelajaran yang sangat bersesuaian dengan prinsip kontekstualitas pembelajaran di kelas ini. Pada model pembelajaran tematik terpadu, materi pembelajaran yang disampaikan oleh guru seharusnya akan dapat diaplikasikan langsung oleh siswa dalam konteks kehidupannya sehari-hari.

6. Pendekatan pembelajaran tematik terpadu IPA dan IPS menganut prinsip mastery learning (belajar tuntas)

Di kelas siapapun guru pasti maklum betul bahwa kecepatan belajar siswa sangatlah variatif dan beragam. Hal ini harus diakomodasi oleh guru sehingga semua siswanya memperoleh kesempatan untuk menguasai materi ajar. Dalam model pembelajaran tematik terpadu, siswa-siswa yang relatif mengalami keterlambatan dalam menyelesaikan program belajar dimungkinkan untuk mengejar ketertinggalannya dengan dibantu oleh guru melalui pemberian bimbingan khusus dan penerapan prinsip belajar tuntas. Selanjutnya, dengan program pembelajaran yang bersifat ramah otak 
memungkinkan guru untuk mewujudkan ketuntasan belajar dengan menerapkan variasi cara penilaian.

\section{H. Guru dalam Pembelajaran Tematik Integratif IPA dan IPS}

Perubahan kurikulum 2013 dengan pembelajaran Tematik integratif IPA dan IPS berimplikasi terhadap beban kerja guru. Segala tugas guru di luar kelas, seperti evaluasi proses akan dikonversi ke dalam pengakuan, sehingga beban kerja guru tidak hanya dihitung saat mengajar tatap muka di depan kelas. Hal ini tidak lepas dengan faktor bertambahnya jam pelajaran pada jenjang pendidikan dasar ini, 4 jam untuk Madrasah Ibtidaiyah.

Beban kerja guru paling sedikit memenuhi 24 jam tatap muka dan paling banyak 40 jam tatap muka dalam seminggu. Evaluasi ini diperlukan mengingat beban kerja guru akan bertambah seiring pelaksanaan pembelajaran tematik integratif IPA dan IPS. Penambahan beban ini sebagai dampak metode pengajaran di MI yang menerapkan pola tematik integratif IPA dan IPS.

Faktor sangat penting dalam keberhasilan atau kegagalan dalam pelaksanaan pendekatan ini adalah guru. Pemerintah sudah berupaya sangat keras untuk meningkatkan kompetensi guru melalui berbagai strategi. Salah satunya adalah peningkatan kesejahteraan guru melalui program sertifikasi. Namun, sayangnya, survei Bank Dunia menunjukkan bahwa sertifikasi guru ternyata tidak mengubah perilaku dan praktik mengajar guru serta belum meningkatkan prestasi guru dan siswa secara signifikan (Napitupulu, 2012).

Oleh karena itu betapa pentingnya kesiapan guru dalam mengimplementasikan pendekatan integratif IPA dan IPS selain kompetensi, komitmen dan tanggung jawabnya serta kesejahteraannya yang harus terjaga. Peran penting guru yang seharusnya dikuasai guru dalam implementasi pendekatan ini, yakni (1) manajemen kelas, (2) metode mengajar, (4) upaya pengembangan karakter, (3) kemampuan menjabarkan topik-topik bahasan pada mata pelajaran menjadi informasi yang menarik IPA dan IPS dan mudah dipahami oleh peserta didik, (4) kemampuan untuk mengidentifikasi tingkat dan area kesulitan peserta didik dan kemampuan untuk membantunya keluar dari kesulitan tersebut, dan (5) kemampuan melakukan evaluasi kemajuan 
belajar siswa. Berdasarkan hasil evaluasi guru dapat menentukan strategi untuk menentukan metode pembelajaran yang lebih tepat dan kecepatan dalam memberikan informasi berupa pengetahuan kepada peserta didik.

Kompetensi guru bukan saja menguasai apa yang harus dibelajarkan (content) tapi bagaimana membelajarkan siswa yang menantang, menyenangkan, memotivasi, menginspirasi dan memberi ruang kepada siswa untuk melakukan keterampilan proses yaitu mengobservasi, bertanya, mencari tahu, merefleksi sebagaimana dinyatakan filosof Betrand Russel "More important than the curriculum is the question of the methods of teaching and the spirit in which the teaching is given". Kurikulum penting, tetapi yang tak kalah pentingnya juga adalah bagaimana pendekatan membelajarkan dan spiritnya. Dengan strategi pembelajaran yang tepat dalam mengimplementasikan kurikulum disertai dengan spirit pendidikan yang selalu menggelora pada setiap guru atau pendidik dan peserta didik, maka proses pendidikan itu sendiri tidak terlepas dari rohnya. Sebuah kata bijak mengatakan bahwa "At-Thariqatu Afdalu Minal Mad" (Metodologi tidak kalah pentingnya dibanding substansi/materi). Betapapun baiknya kurikulum yang telah dikembangkan, buku pelajaran dan media pembelajaran disediakan serta dilaksanakan diklat baik kepala sekolah, pengawas, guru inti, guru pelatih maupun diklat guru secara massal pada akhirnya berpulang kepada ada tidaknya kemauan untuk berubah (willingness to change) dari para pemangku kepentingan utama pendidikan tersebut.

\section{Kesimpulan}

Pembelajaran berbasis tematik integratif di kurikulum 2013, mata pelajaran IPA dan IPS bukan berarti dihapus dari kurikulum, tapi diintegrasikan berdasarkan tema. Mata pelajaran IPA dan IPS menjadi materi bahasan di semua mata pelajaran di Madrasah Ibtidaiyah. Pengintegrasian tersebut dilakukan dalam dua hal, yaitu integrasi sikap, keterampilan dan pengetahuan dalam proses pembelajaran dan integrasi berbagai konsep dasar yang berkaitan. Tema merajut makna berbagai konsep dasar sehingga siswa tidak belajar konsep dasar secara parsial. Dengan demikian pembelajaran IPA 
dan IPS memberikan makna yang utuh kepada peserta didik seperti tercermin pada berbagai tema yang tersedia.

Pendekatan ini sesuai bagi siswa-siswi MI karena dari sudut pandang psikologis, mereka belum mampu berpikir abstrak untuk memahami konten mata pelajaran yang terpisah, khususnya kelas 1,2, dan 3. Proses pembelajaran masih bergantung kepada objek kongkret dan pengalaman langsung. Dengan ini maka suasana kelas yang nyaman dan menyenangkan, siswa belajar memecahkan masalah sosial dan saling menghargai, memberikan peluang sebesar-besarnya bagi siswa untuk belajar dengan lebih baik, memberikan kecepatan proses pengolahan informasi oleh siswa, menerapkan materi pembelajaran langsung dalam konteks kehidupan sehari-hari, dan menganut prinsip mastery learning.

\section{Daftar Pustaka}

Kementerian Pendidikan dan Kebudayaan. 2013. Materi Sosialisasi Kurikulum 2013 untuk Asesor Sertifikasi Guru, di Rayon 111 Universitas Negeri Yogyakarta, Juli 2013.

Marzano, Robert J.. 1992. A Different Kind of Classroom: Teaching With Dimensions of Learning. North Beauregard St. Alexandria: Assn for Supervision \& Curriculum

Napitupulu, Ester Lince.2012. Sertifikasi Guru Tak Kunjung Angkat Prestasi. Kompas 18 Desember 2012.

Piaget, Jean. 1950. The Psychology of Intelligence. United Kingdom, London: Routledge \& Paul

Poerwadarminta, W.J.S.. 1983. Kamus Umum Bahasa Indonesia. Jakarta: Balai Pustaka.

Schacter, Daniel L., Daniel T. Gilbert, Daniel M. Wegner, 2011. Psychology. Edisi kedua. New York: Worth Publishers. 